near Bayeux, on the 3 rst of May, r88o. His name is honourably associated with experimental researches in a good many of the less-frequented bye-paths of electrical science. Living in a time which may well be regarded as the transition period, during which electricity has passed from the stage of a phenomenal and experimental science to one of exact mathematical relations, some of Gaugain's investigations are already superseded by the later and more comprehensive researches of a younger generation. Yet he has done good work, which will live to carry down his name along with that of Peltier, of Pouillet, and of Becquerel, and with the still greater names of Arago and of Ampère.

His earliest contribution to science of which we are aware was a memoir published in 1853 , under the title "Note sur les Signes Electriques attribuées au Mo'ıvement de la Chaleur," and in the same year he brought out his tangent galvanometer. The essential point of this instrument consisted in employing as a coil several turns of wire of increasing diameter arranged about a conical surface, at whose imaginary apex was placed the small magnetic needle, each of the coils thus subtending the same solid angle at this point. This arrangement, to which Gaugain was experimentally led, was in some points virtually anticipated by the tangent galvanometer of Helmholtz, in which, however, a symmetrical arrangement was employed. In the same year Gaugain announced the discovery that continuous currents of electricity could be produced by the continuous friction of two dissimilar metals upon one another. The next two years saw him employed in investigating the electricity produced by evaporation and by combustion. In 1856 he produced his double-condenser electroscope, designed, like the condensing-electroscope of Volta, for the investigation of the electrification due to contact of dissimilar substances. At the same time he published some observations on the behaviour of amalgams of sundry metals, and showed that in a voltaic pair the amalgam of zinc was more electropositive than zinc itself, while the amalgam of cadmium was on the other hand, more electro-negative than the pure metal. From 1856 to I859 Gaugain was occupied with important inquiries on pyroelectricity, and he succeeded in establishing sundry laws, with respect to the electricity of the tourmaline in particular, which had escaped previous observers. The results he arrived at were publishedin the Annales de Chimie et de Physique, and comprised a number of curious and unexpected results. The tourmaline, which at ordinary temperatures is a bad conductor, even for high-tension electricity, begins to conduct at $400^{\circ}$ or $500^{\circ} \mathrm{C}$., and on cooling is still found to conduct; but if washed in water and dried carefully it once more insulates. All tourmalines are not equally active, those of Brazil, green or blue in colour, being the most electrical. In order to obtain a measure of the amount of electricity furnished by a tourmaline whose poles were united by a metallic circuit, he devised a discharging gold-leaf electroscope, and by means of this instrument showed that a number of tourmalines united by their similar poles gave quantities of electricity proportional to their number, while if united in single series they gave no more than a single long one, thus behaving like batteries of great electromotive force and of almost infinite internal resistance. The quantities of electricity furnished by tourmalines of equal lengths but of different thickness while passing through equal ranges of temperature he found to be proportional to the cross-sections of the crystals, again agreeing with the law of $\mathrm{Ohm}$ as applied to batteries of very high internal resistance. Gaugain also showed the quantity of electricity thus flowing through the tourmaline in one direction during a rise of temperature to be equal to that flowing in the reverse direction during a corresponding fall. The year following the discharging electroscope was usefully employed in verifying Ohm's law as applied to other bad conductors. Volta's contact theory occupied Gaugain at several periods of his career, and he established amongst other interesting results that there is a difference of potential between a piece of platinum which has been dipped into acid, and one which has been dipped into alkali, even though both have been subsequently washed. Gaugain also conducted a number of careful researches on specific inductive capacity, on the capacity of cables, on the residual charge of condensers, and on what he termed the variable electric state of a condenser communicating with the soil by a bad conductor, in which, when discharged by disruptive sparks or by the discharging electroscope, the timeintervals of the discharges were found to form a geometric progression. His extended observations on condensers of spherical, cylindrical, and flat forms were communicated to the Académie des Sciences in three special notes. In later years Gaugain devoted himself to the examination of the effects of heat upon the magnetism of steel tubes and bars, and found the remarkable result that a bar magnetised powerfully while hot may when cooled exhibit a reversed polarity, and vice versa $\hat{a}$; also that the magnetisation by a strong current penetrates deeper than that due to a weaker current. He also brought to light sundry analogies between the behaviour of magnets under magnetic force, and of matter generally under mechanical forces.

Born in Normandy in 18 ro, he entered the École Polytechnique at about the age of eighteen, and afterwards attended the École d'Artillerie at Metz, after which he adopted metallurgy as his profession. Gaugain worked during the closing years of his life in isolation and in straitened circumstances, assisted by his only daughter, who devoted herself to him. His researches, though several times rewarded with academic recognition, were not in themselves productive of gain ; and the prix Gegner, an annual grant of 4,000 francs, given dun savant pauvre afin de laider dans ses recherches, awarded to him for five years past, was a welcome amelioration of his position in a time of failing health and during the painful illness to which he succumbed at the age of seventy years.

S. P. T

\section{A CHAPTER IN THE HISTORY OF THE CONIFERAE}

$\mathrm{T}$ working out the Eocene coniferæ, in continuance of the monograph which the Palæontographical Society are kindly publishing and illustrating in a sumptuous manner, some reflections upon the past history of the more prominent Eocene genera, such as Araucaria, Podocarpus, Dammara, Sequoia, \&c., have occurred to me, which, although being perhaps outside the scope of the Palæontographical Society's work, may not be uninteresting to the general readers of NATURE. I have therefore tentatively brought forward the present chapter on Araucarias without yet having any definite intention of putting together my notes upon the other genera, in the present form.

Araucar $i a,{ }^{1}$ Jussieu.- The earliest traces of distinctly coniferous wood known, those from the Carboniferous, were for many years thought to belong exclusively to the Araucarian type. This supposed prototype became, according to Schimper, modified in successive ages, and he endeavours to trace these modifications through the extinct genera Walchia, Ullmannia, Araucarites, Voltzia, Ptycholepis, Pachyphyllum, and Cunninghamites. Lesquereux, however, carries the actual genus Araucaria to as far back as the Trias, and unmistakable cones of both sections of the genus have been described by Carruthers from the Stonesfield, Yorkshire, and Somersetshire oolites; fossil forms agreeing closely with these have been also found in the Jurassic of India. It is not

x From Araucanos, a people of Chili, in which country A. imbricata abounds, and furnishes the principal food of the Indians. 
definitely known at present in cretaceous rocks, for the large fossil cone figured by Heer as Araucarites nordenskiöldi, from the upper cretaceous of Spitzbergen, is a very indistinct coaly mass, and as he suggests, possibly cycadaceous. $^{x}$

The Araucarias thus appeared to have declined since Jurassic times, and Schimper states that, with the Tertiaries, they became extinct in Europe. Thiselton Dyer ${ }^{2}$ goes further, and has even stated that, so far as we know, they have been extinct north of the equator since the Oolitic age. It is certain, however, as I hope to show, that at least one section of them abounded in Europe during the Eocene age, and probably did not quit it until the Miocene.

The existing Araucarias present a singular appearance when contrasted with other trees, and would be looked upon from their aspect alone as unmistakably archaic in character. They have been divided by Salisbury ${ }^{3}$ into two very distinct sections: Columbea, or true Araucarias, and Eutacta, or the needle-leaved false Araucarias. They are exclusively confined to the southern hemisphere, Columbea alone being represented in South America, and both sections in Australia and the adjacent isles.

The section Columbea possesses but four species, which are, however, very distinct from each other and of great interest. The most familiar is the common Araucaria imbricata, or Monkey-puzzle. It is almost confined to Chili, forming vast forests which extend upon the slopes of the Andes from the snow-level to about 1,500 or 2,000 feet downwards. The trees reach 150 feet in height, and with their dark pendulous foliage are of imposing grandeur. Their appearance when full grown can scarcely be realised from the young trees in England, but an exceptionally fine specimen is at Windsor, and a carriagedrive leading to a nobleman's house, near Armagh if I remember rightly, is bordered by high banks of large and, for our country, well-grown trees of this species, and presents a strikingly dignified effect. The cones are very large, and the seeds, which are highly nutritious, form the staple food of the Indians. The second South American species, $A$. brasiliensis, is somewhat similar in appearance, and reaches 100 feet in height. It also forms immense forests, and produces edible nuts, but as it will not live in our climate without protection, is less frequently seen in cultivation.

The Australian species are even more strange in aspect. Araucaria Bidwillii forms a majestic tree, growing to I 50 feet in height, and confined to a tract 30 miles long by 12 on the east coast near Brisbane, where it far overtops the other forest trees. A. Rulei, a smaller though equally beautiful tree, is chiefly remarkable for its singularly restricted range, being only indigenous to Porte Molle, one of the Caledonian Isles, where it is confined to the summit of an extinct volcano, but half a mile in radius, and exposed to extremes of heat and cold that appear destructive to other kinds of vegetation, for hundreds of feet below it.

The Columbeas have not been met with fossil either in the Eocene or Cretaceous rocks, probably because their stations are mostly high rocky ridges, where there is an absence of water, rendering it unlikely that their remains would find their way into marine or fluviatile sedimentary strata. We must by no means infer, therefore, that species belonging to this section did not exist in Europe contemporancously with the species of Eutacta that have been found.

The section Eutacta has terminal globular cones with broadly-winged and generally persistent scales and falcate

I 'Flora foss. Arctica," vol. iii. Pl. xxxvii. p. r26. Heer says the figure is much too distinct, and that the position and arrangement of the scales can only be made out with the greatest trouble. Restored as it is, it possesses no distinctively Araucarian characters, while no branches of Araucaria have becn found that could be placed with it. Cycadaceous and Sequoia foliage moreover abounds in most cretaceous rocks in high latitudes.

2 Royal Geog. Soc. Proceedings, I878, vol. xxii. p. 427.

3 Trans. Linn. Soc., vol. viii., I807, pp. 308-317. needle-like leaves. There are but three existing species, all of gigantic dimensions, for two of them attain a height of over 200 feet, and the third 150 feet. Anaucaria Cookit, or the Norfolk Island pine, a native of New Caledonia and New Hebrides, presents a fantastic columnar-like growth, giving the trees when seen from a distance somewhat the appearance of a grove of ship's spars 200 feet or so in height. $A$. excelsa, indigenous to Australia and Norfolk Island, is an even more majestic and colossal tree, towering to a height of 230 feet, with a trunk of some 30 feet in girth. The third species, $A$. Cunninghami, I wish to describe in more detail, for I have ascertained, conclusively I believe, that it, or a species indistinguishable from it, flourished abundantly in our latitude and longitude in the Middle Eocene period.

A. Cunninghami, like many Coniferæ of the southern hemisphere, has two slightly distinct forms of leaf, those of the young plants being straighter, more sabre-like, and horizontally disposed than those of the more fully developed tree, which hitherto have alone been met with fossil.

The foliage of the more full-grown tree is composed of moderately short falcate needle-like leaves, quadrangular in section, thickening at the base, and with the lower side produced and decurrent on the stem. These are disposed all round the branches, and leave the stem at first at right angles to it, and then gently curve upward and inward. This arrangement causes each leaflet to be free or seldom in contact one with another, and is an important character in distinguishing the species by its foliage when other organs are absent. The terminal branchlets are generally simple for 5 or 6 inches, and then branch shortly but copiously, and chiefly horizontally. These branchlets apparently represent one year's growth, for they are articulated at the base, and are annually shed in abundance by the trees. Branchlets resembling these in the minutest particulars are to be found in great quantities in the Eocene beds at Bournemouth.

Other coniferous foliage, however, resembles $A$. Cunninghami, especially that of some of the cultivated Sequoia gigantea, so much so that I had difficulty in removing the prejudice from Ettingshausen's mind, shared by all the Teutonic palæobotanists, in favour of referring all this type of foliage to Sequoia. Before it can definitely be said to belong to $A$. Cunninghami these types of foliage must of course be considered.

In the first place the foliage of $A$. Cunninghami is easily distinguishable from that of the other Araucarias in the section; $A$. excelsa having leaves more at right angles, more laterally disposed, and foliage less branching, and $A$. Cookii possessing the leaves broader and in contact with an imbricated appearance, while every articulated branch is simple. The other Coniferæ which resemble it are Creptomeria japonica, in which the leaves are mucb longer and straighter, and quit the stem at an angle of about $35^{\circ}$; Arthrotaxis selaginoides and Dacrydium araucaroides, which have the imbricated appearance of $A$. Cookii; and Sequoia gigantea, which is much the nearest in general habit. The leaves of Sequoia differ in being rather longer in proportion, less regularly disposed and curved, leaving the stem at a very acute angle, and hugging it more closely, so that their points irregularly overlap and touch each other. Its foliage in the wild state seems always to be very much smaller, and the larger foliage it seems sometimes to assume away from its native habitat, shows very distinctly the seasonal variations in the size of the leaves so characteristic in the other existing Sequoia, $S$. sempervirens. The Bournemouth foliage differs from all these materially, but as already stated, resembles that of Araucaria Cunninghami in so close a degree as to be indistinguishable from it by any discoverable character.

Apart from the foliage, however, there is other evidence in support of the view that this is really Araucaria 
Cunninghami. Although the branchlets are most abundant in some of the beds, both marine and freshwater, no trace whatever of the cones could be found. I was at first.surprised at this, for it is generally more common in beds of marinc origin, as at Brackleslsam, Barton, Sheppcy, \&c., to meet with cones than with foliage, and no instance of the presence of coniferous foliage only, in a sea-deposit of any age had previously come under my notice. I was so puzzled that I spent several days in digging and tracing out these branchlets and vainly trying to find the attached fruits-the cause of whose absencc should have been clear. The concs, 3 incbes long and nearly 9 inches in diamcter, are so exceedingly dense and heavy that they have no power of flotation, and their presence in beds of fine drifted sediment could therefore anly bo due to some rare accident. On the other hand, the small light cones of Sequoia would, like those of Pinus, everywhere drift by flotation, and necessarily not unfrequently become imbedded with the foliage. Although I found no cones, the female terminal buds present the peculiar constriction and then swelling, so characteristic of Araucaria.

The distribution of Araucaria Cunninghami at Bournemouth is very clearly defined, and tells as plainly as possible that its habits when existing in our latitudes did not differ from those it now posscsses. No tracc of it is met with rest of the pier in the beds whose floras may be thought, from their characters, to bave come from districts away from the sea-but east of the pier it abounds cicrywhere, in company with fan-palms, eucalyptus, aroids, ferns, \&.c., and in certain beds of mud and muddy sand of the marinc serics, the branchlets, in marvellous preservation, are secn to cross each other in every direction.

The existing Araucaria Cunningrhami forms vast forests on the shores of Moreton Bay, on the alluvial banks of the Brisbane River, and grows in the greatest profusion in the brush forests of the Richmond River. "The trees seem to thrive best near the coast, attaining in such a situation their greatest height, often from 100 to 130 fect, but gradually diminishing in height the farther the trees are inland. It would appear from this that the sea air has a great effect upon it."

The "brush" forests, in which $A$. Cunninghami very gencrally occurs, although it is not exclusively confined to them, are thus described by Moore:-

"The 'brush' is characterised by denseness of growth, the altitude and beautiful dark green foliage of the trees, the presence of lofty climbing plants, which extend their slender pliant branches considerable distances, and by this means often embracing, as it were, into one common bond, many of the loftiest and largest trees. . . . Another characteristic of forests of this description is a thick undergrowth of numcrous kinds of ferns and other plants. Palms and tree-ferns also usually abound, the former reaching a height, in some instances, of at lcast 130 fect. ... On the stems and branches of the trees numcrous kinds of epiphytal ferns and archids grow, which, with the other plants referred to, contribute materially to give such forcits a very tropical appearance." :

It is clear, from the debris of trailing Smilacere and Aroids, and from the remains of large fan-palms and ferns, that our Eoccne "brush"-growth must have been very similar to this in appcarancc. The physical aspects of the former stations of Araucaria on the alluvial banks of the great Bournemouth River in close proximity to the sea, as we have asccrtained, and its probable extension along the shores of what must have been the eirst coust of the submerged continent seem to approximate to those it now occupies on the Brisbane River and the shores of Moreton Bay on the cast coast of Australia. Nothing

I Iso feet. "Industrial Progress of New South Wales; Official Report of the Sydney Exh.bition, 1870 ." Part II. p. 643. It is astonishing how very generally the dimensious of the Cunifirat of Australia and Anerica are generally the dimensious of the Cumifira: of Australial and Anerica are
under ectimated. 2.0. ، il., p. 633 . can be more impressive indecd than the remarkable agrcement in habit, as far as we can trace, between the Aritucaria and associated plants that have passed away and those that survive. The long-imbedded plants of our Eocenc coasts seem to have risen up and to live again in this far-off country, and by what we sce there we are able to picture the long sandy coasts, beaten by an ocean surf and fringed with dark-foliaged and gigantic $\Lambda$ raucarias, gum-trees, luxuriant palms and ferns, whose remains have helped to form the present pine and heatherclad cliffs of Bournemoutb. If we contrast this with the comparative absence of any associated vegetation in the Mammoth Grove, we see how opposed the intended reference of these branches to Sequoia would have bcen to any known natural grouping.

Elscwhore in Great Britain we have little trace of anything referable to Araucaria younger than in the Jurassics, except certain foliage at Shcppey and the foliage from the basalt of Antrim, referred by Bailey to Sequoia as $S$. $d u$ Noyeri, about which however I am not yet able to express an opinion. In France, from many Eocene localities, undoubted Araucaria branches have becn obtained, though none of them seem to be specifically identical with ours, and some appear more of the 1. creclsa type.

In Central Europe, from Sotzka, Häring, Monte Promina, Bilin, \&c., in Tertiary beds whose exact age is not yet satisfactorily detcrmined, a somewhat similar foliage abounds. This was originally described as Araucarites, and indeed at Hiring a young cone with every characteristic of Araucaria was found in the same bed with it. All of them were subsequently tranjferred to Sequoia, which many certainly more ncirly resenible in the direction and arrangement of the leaves; yet the absence of any Sequoia cones which can, so far as I know, be directly connected with them, and the presence of a characteristic Araucaria cone should, at all events, inducc caution in believing the whole of this type of foliage met with in Central Europe during the Middle or Upper Eocene to belong to an ally of Sequoia gigantca. It is quitc open to doubt whether, as Hcer's determination of two fragments would imply, this species known as S. stirnberseri, whatever its real character may bc, persisted as late as the Miocene of Oeningen. On the other hand, the presence of fossil Sequoiæ of the Wellingtonia type within the Arctic circle is undoubted, though Hecr appears to have madc more species than werc nccessary.

The presence of an Araucaria, indistinguishable from A. Cunninghami, in our latitudes at a time not more remote than the Middle Eocene, is of interest, for although many of our Eocene plants have been referred to Australian genera, there has alivays bcen doubt sufficient to render any confirmation of the supposed land connection with Australia of importance. While the association with it at Bournemouth, of Podocarps and Dammara, Eucalyptus, and many Proteaceæ, which arc strictly forms of the southcrn hemisphere, is but natural, the presence of a nccdle-leaved conifer of the genus Pinus, even rare as it is, is singular. Such a union nowhere takes place at the present day, although in Mexico pines mingle with feather palms.

The prescnce in $\mathrm{N}$. lat. $50^{\circ}$ of a fora, now distinctive of the sub-tropics of the southern hemisphere, and of a north temperate flora in $\mathrm{N}$. lat. $7 \mathrm{O}^{\prime \prime}$, during the Eocene period, can hardly fail to provoke wonder as to where the eqt:ator of heat was then situated. It is impossible to suppose that the equator of heat scparated them as it does now, however far north it might be driven by shutting off the Arctic currents and leaving those of the Antarctic to circulate. Yet if the southern bemisphere flora wcre formerly to the north of the equatorial zone of heat, the quastion must arise as to how Araucaria Cunninghami, 37. 
and other forms that are not tropical, could have reached their present habitat. The range of this Araucaria, although greater by far than that of the other Eutactas, is very definitely limited to a strip of coast in New South Wales between the Bellingen, a small stream about S. lat. $31^{\circ} 40^{\prime}$, and Cape York in Queensland, in nearly $10^{\circ} \mathrm{S}$. lat. It does not approach, therefore, to within nearly a thousand miles of the equator of heat, which is several degrees north of the true equator. They must either have crossed the equator from the south in præeocene times and subsequently become isolated and died out in their northern habitat, or have been originally indigenous to the north and retreated to their present stations. A passage must have been made in either case, for the present distribution of Coniferæ is against the supposition that any identical species could have extended synchronously in lowlands in both hemispheres, widely separated by the equator. If a general lowering of temperature had favoured their passage, the pre-existing tropical vegetation must have altogether died out, and the existing equatorial vegetation would present a comparatively new aspect. The absence of any of the Coniferæ that have ever been met with fossil in the plains of the tropical regions at the present day, and of any existing strictly equatorial plants, such as Gneta among Conifers, in the fossil floras, seems at first sight to show that it does do so and therefore lends some colour to what is at best merely a very crude hypothesis. A simpler supposition than that of a general lowering of temperature in the Tropics, until more facts are forthcoming, is that the passage was effected across high land, some of which may still remain in Sumatra and Java.

The specific identity which is apparent, of this and other Australian forms, with those of our Eocenes, proves that some, at all events, of the at present purely Australian gencra, neither originated norbecame differentiated, as Ben. tham supposed, in Australia. The endemic genera, he says, never spread far out of it, the only exceptions appcaring in the Malay Archipelago, "especially Timor, New Guinea, and Borneo, and a few as far as Southern China." 1 Nothing could speak more eloquently of the path the migrations have taken, than these remnants left upon the road, nor go farther to prove the former connection with our antipodes, which the discovery in 1814 by Brown of 150 European plants, a number since greatly increascd, growing endemically in Australia, first of all I believe suggested to us.

It may not be altogether a useless supposition to hazard, that if, as Saporta supposes, plants originated mainly if not wholly in northern regions, and migrated south, the continents of the southern hemisphere may be actually preserving, as in the present case, our Eocene flora, and have been inhabited in Eocene times by the Jurassic flora which preceded it, or by some intervening flora of which we have now but the scantiest records.

From what has been said the Araucarias are seen to be an archaic type, formerly most widely spread, now dying out and only lingering in restricted areas in the southern hemisphere, whose very specific differentiation was accomplished before the Eocencs began. May its value as food and use as the chief timber tree in the districts it still inhabits preserve it from an accelerated extermination at the hands of man.

J. Starkie Gardner

\section{ON SOME POINTS CONNECTED WITH}

TERRESTRIAL MAGNETISM

THE remarks in NATURE, vol. xxii. p. 169, of Messrs. De La Rue and Müller in connection with their most interesting and important researches on rarefied gases induce me to ask the privilege of stating somewhat more fully than I did on June 17 what I conceive to be the

\footnotetext{
× Bentham, "Flora Australice sis," vo'. vii.
}

position filled by a working hypothesis such as that then mentioned in the science of terrestrial magnetism. Let me begin with the aurora. Here we have a phenomenon which invariably accompanies magnetic storms, on which occasions it occurs simultaneously over a large portion of the globe. Again the recent researches of the abovenamed gentlemen render it very probable that auroral displays do not occur at a very great height, while it is conceivable that they may occur at times at an altitude of a few thousand feet. Here then we have a phenomenon which is intimately connected with sudden changes of the earth's magnetism. To this we may add earth currents as another phenomenon of the same kind, so that we have earth currents and auroral displays invariably associated with magnetic storms, when these are of marked violence. Now what is the nature of this connection? When we examine the formal laws of these associated phenomena we find that these lead us (almost irresistibly, as I think) to conclude that earth currents and auroræ are secondary discharges caused by sudden changes in the earth's magnetism, no matter how these changes are produced. So strong is the evidence of form in this instance that the late eminent magnetician John Allan Broun expressed to me his belief that earth currents and auroræ were connected with magnetic storms in the way above mentioned.

If this be assumed as the most probable working hypothesis, it is natural to take another step. If we have discharges produced in stationary strata by a changing magnet, may we not have discharges produced in moving strata by a constant magnet, and may not the motions and changes of motion produced by the sun in the upper convection currents of the earth give rise to electric phenomena which may explain the changes of terrestrial magnetism? Of course this is only a working hypothesis. Before it can possibly become an established theory we must have obtained from Messrs. De la Rue and Müller and from other observers that full and complete information regarding discharges in rarefied media which they are rapidly affording us, and we must likewise have obtained fuller information than we now possess regarding the directions and velocities of the convection currents in the upper regions of the earth's atmosphere. When this is done, the problem may be regarded as ripe for the mathematical physicist who may proceed with his calculations and either dismiss the hypothesis as untenable or increase the probability of its truth.

But in the meantime we are not ripe for this, and all that we can do is to regard the hypothesis as a working one, and endeavour by its means to elicit new facts regarding the form of the diurnal and other variations of terrestrial magnetism. I submit that in this respect the hypothesis has not been devoid of value. I have by its means been led to derive the fact that certain magnetic diurnal changes lag behind corresponding solar changes, just as meteorological changes would do - a fact which has since been confirmed by Mr. Ellis of the Greenwich observatory. And I may be allowed to anticipate the results of work at which I am now engaged so far as to say that in the short periods which I am now investigating an increase or decrease of solar activity corresponds to an increase or decrease both of magnetical and meteorological activity.

Again, in conjunction with others, I have shown by preliminary discussions the probability of a progress of magnetic phenomena from west to east just as we know there is a progress of meteorological phenomena, only magnetic weather (if I may use the expression) appears to travel faster than meteorological weather. This last appears to me to furnish almost a crucial test in favour of this hypothesis, and through the courtesy of the Kew Committee, the Astronomer Royal, and Mr. Carpmael of Toronto I hope to be able soon to investigate this phenomenon in a more complete manner. 